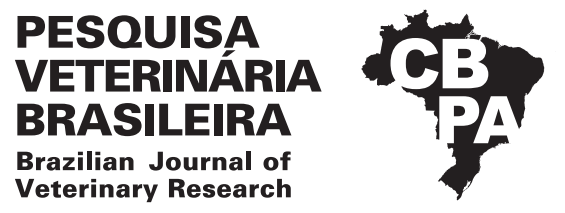

Pesq. Vet. Bras. 38(10):1935-1941, outubro 2018 DOI: 10.1590/1678-5150-PVB-5208

Original Article

ISSN 0100-736X (Print)

ISSN 1678-5150 (Online)

\title{
Age-related changes of the cerebral ventricles of healthy domestic cats ${ }^{1}$
}

\author{
Viviam R. Babicsak ${ }^{2 *}$, Adriana V. Klein ${ }^{2}$, Miriam H. Tsunemi ${ }^{3}$ and Luiz C. Vulcano ${ }^{2}$
}

\begin{abstract}
Babicsak V.R., Klein A.V., Tsunemi M.H. \& Vulcano L.C. 2018. Age-related changes of the cerebral ventricles of healthy domestic cats. Pesquisa Veterinária Brasileira 38(10):1935-1941. Departamento de Reprodução Animal e Radiologia Veterinária, Faculdade de Medicina Veterinária e Zootecnia, Universidade Estadual Paulista, Campus de Botucatu, Rua Prof. Doutor Walter Mauricio Correa s/n, Botucatu, SP 18618-681, Brazil. E-mail: viviam.babicsak@gmail.com

This study aimed to determine age-related changes of the cerebral ventricles of healthy non-brachycephalic domestic cats by the acquisition of brain MRI images of 12 adult ( 1 to 6 years), 11 mature ( 7 to11 years) and 10 geriatric ( 12 years or more) cats. Our hypothesis is that the cerebral ventricular system of cats expands with increasing age. The possibility of the evidence of the olfactory bulb cavities and temporal horns of the lateral ventricles were evaluated in this study. Volumes of the olfactory bulb cavities, lateral ventricles (including the temporal horns), third ventricle, mesencephalic aqueduct and fourth ventricle were measured and corrected for the intracranial volume. Significant differences were found between the adult and mature groups in relation to the geriatric one for the variable related to the evidence of the temporal ventricular horns, which were most frequently visualized in geriatric cats. Percentage of the right lateral and third ventricles volume by intracranial volume were significantly higher in geriatric cats compared to the adults. The results of this study demonstrate that ventricular dilation tends to occur with advancing age in cats, as well as the increase in the frequency of the temporal ventricular horn evidence, as had been indicated in the hypothesis of the study.
\end{abstract}

INDEX TERMS: Aging, cerebral ventricles, cats, brain, neuroanatomy, magnetic resonance imaging, dilation, morphology.

RESUMO-- [Alterações senis dos ventrículos cerebrais de gatos domésticos hígidos.] 0 estudo objetivou a determinação das alterações senis dos ventrículos cerebrais de gatos domésticos hígidos não braquicefálicos pela aquisição de imagens encefálicas de 12 indivíduos adultos ( 1 a 6 anos), 11 maduros ( 7 a 11 anos) e 10 geriátricos (12 anos de idade ou mais) por ressonância magnética. Nossa hipótese é de que o sistema ventricular dos gatos se expande com o avanço da idade. A possibilidade de evidenciação das cavidades do bulbo olfatório e dos cornos temporais dos ventrículos

\footnotetext{
${ }^{1}$ Received on April 24, 2017.

Accepted for publication on December 21, 2017.

${ }^{2}$ Departamento de Reprodução Animal e Radiologia Veterinária, Faculdade de Medicina Veterinária e Zootecnia (FMVZ), Universidade Estadual Paulista (Unesp), Campus de Botucatu, Rua Prof. Doutor Walter Mauricio Correa s/n, Botucatu, SP 18618-681, Brazil. *Corresponding author: viviam.babicsak@gmail.com

${ }^{3}$ Departamento de Bioestatística, Instituto de Biociências, Universidade Estadual Paulista (Unesp), Campus de Botucatu, Rua Prof. Doutor Walter Mauricio Correa s/n, Botucatu, SP 18618-681.
}

laterais foi avaliada nesse estudo. Os volumes das cavidades do bulbo olfatório, ventrículos laterais (incluindo os cornos temporais), terceiro ventrículo, aqueduto mesencefálico e quarto ventrículo foram mensurados e corrigidos de acordo com o volume intracraniano. Diferenças significativas foram encontradas entre os grupos dos adultos e maduros em relação aos geriátricos para a variável referente à evidenciação dos cornos temporais, que foram visualizados de forma mais frequente nos gatos geriátricos. A porcentagem do volume do ventrículo lateral direito e do terceiro ventrículo em relação ao volume intracraniano foi significativamente maior nos animais geriátricos em comparação aos adultos. Os resultados desse estudo demonstram que a dilatação ventricular tende a ocorrer com o avanço da idade nos gatos, assim como o aumento na frequência da evidenciação dos cornos temporais, como havia sido indicado na hipótese do estudo.

TERMOS DE INDEXAÇÃO: Senilidade, ventrículos cerebrais, gatos domésticos, neuroanatomia, ressonância magnética, dilatação, morfologia. 


\section{INTRODUCTION}

Cerebral ventricular system is a complex of intercommunicating compartments filled by cerebrospinal fluid, composed by the olfactory bulb cavities in the rostral portion, followed by the lateral ventricles, which communicate with the third ventricle by the interventricular foramina. The third ventricle surrounds the interthalamic adhesion and is linked with the mesencephalic aqueduct, which intersects the midbrain and connects the third and fourth ventricles. The caudal component of the cerebral ventricular system is the lateral recesses of the fourth ventricle, which are connected to the subarachnoid space (Evans \& DeLahunta 2001, Bagley 2005).

Cerebrospinal fluid is produced in cerebral ventricular system by choroid plexuses of the lateral, third and fourth ventricles at a constant rate of 0.03 to $0.5 \mathrm{ml} / \mathrm{min}$ (Thomas 2010). Cerebrospinal fluid production is independent of intracranial pressure, and therefore, it continues to be produced despite the existence of drainage disorders, resulting in its accumulation and ventricular dilation (Evans 1993, Bagley 2005).

Neoplasm, congenital malformation (cysts, Chiari malformation), infeccion and hemorrhage are examples of brain disturbs that may interrupt cerebrospinal fluid drainage. Brain diseases that cause overproduction of cerebrospinal fluid, such as choroid plexus papilloma or carcinoma, are usually associated to ventricular enlargement, as well as atrophic brain disordes, such as neurodegenerative (Alzheimer's, schizophrenia), congenital inflammatory (toxoplasmosis, cytomegalovirus) and vascular (arteriovenous malformations, multifocal infarctions) disturbs (Eisenberg 2010).

Ventricular expansion, however, is not only related to brain disturbs since several authors concluded that ventricular dilation is a commonly finding observed in normal geriatric humans and canines (Coffey et al. 1992, Borràs et al. 1999, Resnick et al. 2000, González-Soriano et al. 2001, Beason-Held \& Horwitz 2002, Sullivan et al. 2002, Scahill et al. 2003, Su et al. 2005, Walhovd et al. 2005, Pugliese et al. 2010) due to the loss of neuronal tissue (Borràs et al. 1999). Other authors suggest that changes in the dynamics of cerebrospinal fluid with age are also responsible for ventricular enlargement in humans (Scahill et al. 2003).

Since many diseases may lead to ventricular enlargement, the knowledge of normal ventricular changes during senility is essential to enable the differentiation and detection of these disorders.

So far, imaging data correlating the ventricular system of the domestic cats and senility were not found in the literature. Therefore, this study aimed to determine normal changes in brain ventricles of cats with the progression of age by the comparison of MRI images of adults, mature and geriatric cats. Cerebral ventricular volumes were determined in this investigation, as well the possibility of identification of the olfactory bulb cavities and temporal horns of the lateral ventricles. Our hypothesis is that the cerebral ventricular system of the domestic cats expands as the progression of age.

\section{MATERIALS AND METHODS}

This research was approved by our ethics committee on animal experiments (197/2012-CEEA). Cats belonged to owners who agreed to participate in the research and signed consent after the explanation of the procedure and the risks related to anesthesia and contrast administration.
Animals. Thirty-tree neutered non-brachycephalic domestic cats were divided into three groups according to age: the group A included 12 adult cats aged 1-6 years, the group B comprised 11 mature cats aged 7-11 years and the group C comprehended 10 geriatric cats aged 12 years and older (Lund et al. 1999, Fortney 2012, Laflamme \& Gunn-Moore 2014).

In the group of the adults, 2 cats were males and 10 were females. The mean age of this group was $2.00 \pm 0.74$ years ( $1-4$ years) and the average weight was $3.96 \pm 0.69 \mathrm{~kg}$. In the group of the mature cats, 3 were males and 8 were females. The mean age and weight of the mature catss were $8.54 \pm 1.37$ years (7-11 years) and $4.91 \pm 2.80 \mathrm{~kg}$, respectively. In the group of the geriatric cats, it was selected 2 males and 8 females. These cats showed mean age of $14.00 \pm 1.33$ years (12-16 years) and average weight of $4.08 \pm 1.12 \mathrm{~kg}$.

Only cats with no history of neurological signs were selected for the study and, to this end, owners were asked for evidence of neurological disorders such as excessive vocalization, aggression, decreased physical activity, house soiling, compulsive walking, circling, head tilt, head pressing, seizures, blindness, incoordination and tremors.

Neurological physical assessment was performed by a single evaluator, who performed the inspection of the behavior and state of consciousness; observation of gait; proprioception tests; and cranial nerves examinations as eyelid reflex, blink-to-threat reflex, pupillary light reflex, evaluation of pupillary size and hearing test.

Polymerase chain reaction (PCR) for feline immunodeficiency (FIV) and leukemia (FeLV) viruses, blood count, serum biochemistry (urea, creatinine, aspartate aminotransferase, alkaline phosphatase, gamma glutamyl transferase, total plasma protein, albumin, globulin), thoracic radiographs and abdominal ultrasonography were performed in order to ensure the cats were healthy.

Magnetic resonance imaging. Selected cats were anesthetized and, therefore, they were subjected to 12-hours of fasting and 2-hours of water deprivation. After physical examination, it was performed intramuscular administration of acepromazine 0.2\% (Apromazin; Syntec Brazil, Cotia, SP, Brazil) at $0.05 \mathrm{mg} / \mathrm{kg}$ and morphine sulfate (Dimorf; Cristália, Itapira, Brazil) at $0.3 \mathrm{mg} / \mathrm{kg}$. Later, intravenous administration of propofol (Propovan; Cristália, Itapira/SP, Brazil) was performed at $6 \mathrm{mg} / \mathrm{kg}$ or even the loss of laryngotracheal reflection. Cats were placed in right lateral recumbency in MRI equipment, and the skull was arranged inside the most appropriate coil according to its dimensions (coil 3/4; ESAOTE, Genova, Italy). Then, it was performed endotracheal intubation and tracheal tube was connected to Bain circuit. Isoflurane (Isoforine; Cristália, Itapira/SP, Brazil) vaporizer was adjusted to maintain a moderate level of anesthesia. Brain images were acquired in low-field MRI equipment (0.25 Tesla - Vet MR Grande; ESAOTE, Genova, Italy) on transverse T1- weighted sequence (TE: 18ms/TR: 433,333ms). Slice thickness and gap used were $3.0 \mathrm{~mm}$ and $0.3 \mathrm{~mm}$, respectively. Matrix size was 224x192 and FOV was $14 \mathrm{~cm}$. Capnography, pulse oximetry, electrocardiogram, and direct and indirect arterial blood pressure were monitored during MRI.

Image evaluation. Images were evaluated by a single experienced radiologist, blinded to the patient identification, using the medical image software application OsiriX (OsiriX v.6.0.2, OsiriX, Atlanta, GA, USA).

Categorical variables evaluated in this study included the possibility of evidence of the temporal horns of the lateral ventricles and olfactory bulb cavities.

Volumes of the olfactory bulb cavities, lateral ventricles (including the temporal ventricular horn), third ventricle, mesencephalic aqueduct and fourth ventricle were measured by manual delimitation of the ventricular contours (Fig.1-5). Intracranial volume was also determined 


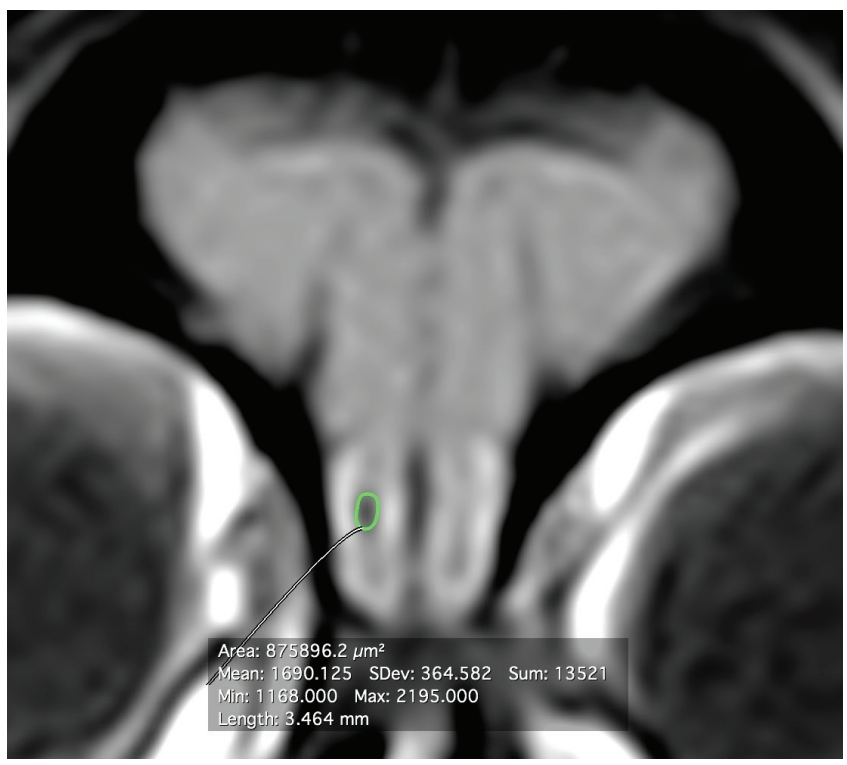

Fig.1. MRI brain image demonstrating volumetric mensuration of the olfactory bulb cavity.

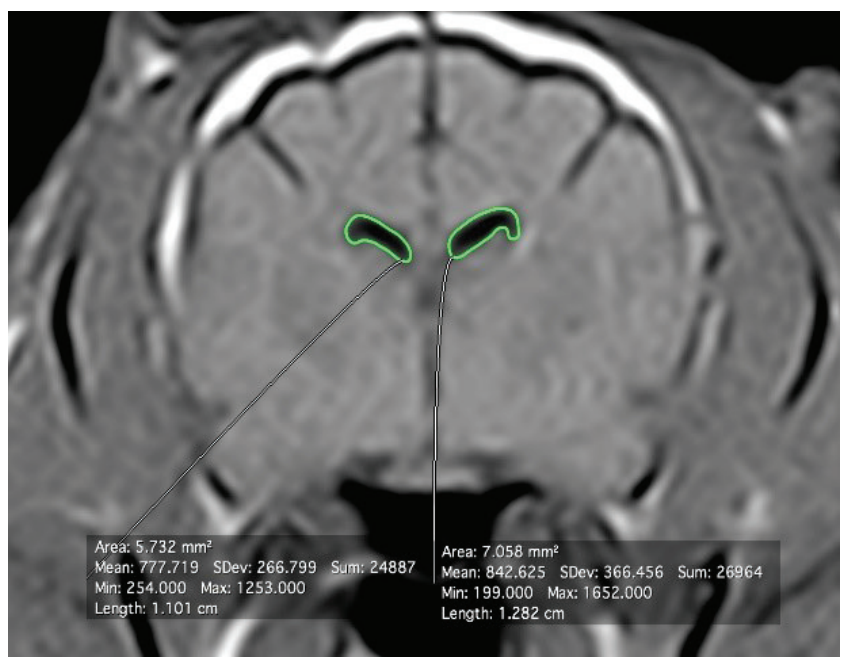

Fig.2. MRI brain image illustrating manual delimitation of the contours of lateral ventricles for volumetric mensuration.

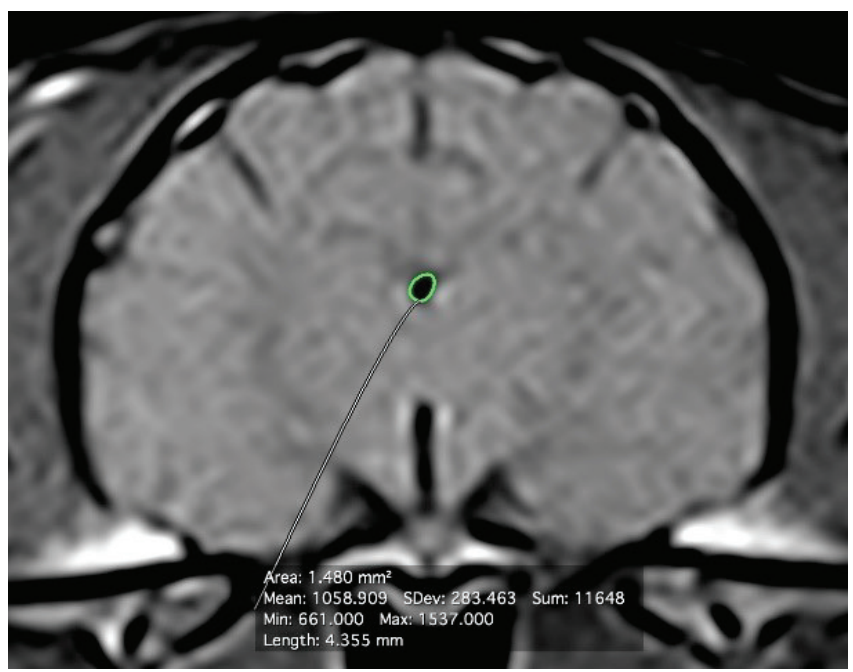

Fig.3. MRI brain image illustrating volumetric mensuration of the third ventricle. in this study and it was used for correction of the ventricular volumes by calculating the percentage of the ventricular volumes in relation to the intracranial volume (ventricular volume x100/intracranial volume). Subsequently, the results of the percentages of the volume of each ventricular structure by intracranial volume were summed to obtain the value related to the percentage of the total ventricular volume. The results of the continuous parameters analyzed in this study are mean values of the measurements performed in triplicate by the evaluator.

Statistical analysis. Statistical analysis was performed using the software SPSS 17.0 (SPSS Inc., Chicago, Illinois, USA). The analysis of the categorical variables related to the evidence of the temporal ventricular horns and olfactory bulb cavities were performed using Fisher's exact test and chi-square test, respectively. ANOVA test was used to the comparison of the average values of the continuous variables with normal distribution. Later, Bonferroni multiple comparison test was performed to compare the mean values of the parameters with significant $p$-values, except for the variable "percentage of the total ventricular volume by intracranial volume",

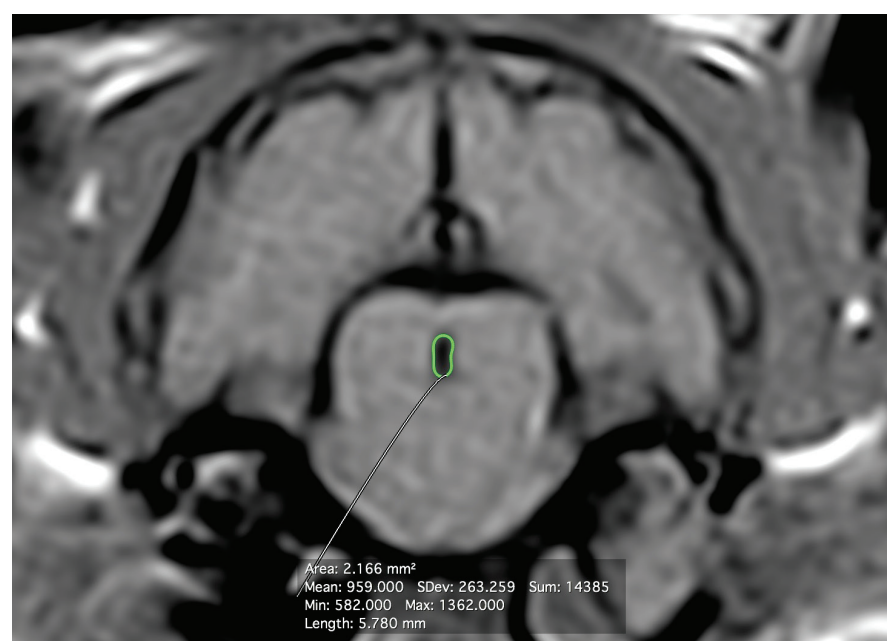

Fig.4. MRI brain image demonstrating manual delimitation of the contours of mesencephalic aqueduct for volumetric mensuration.

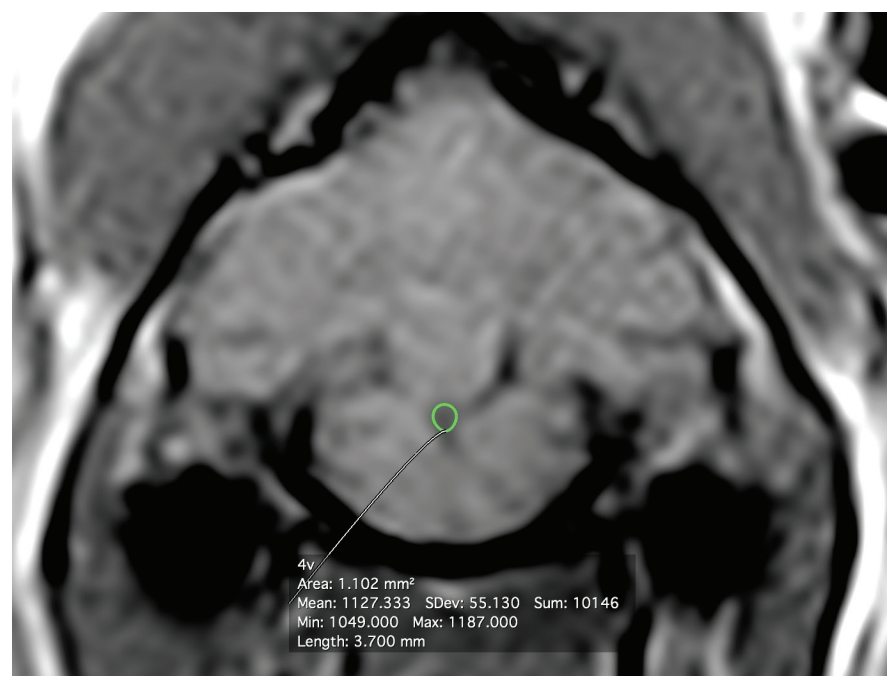

Fig.5. MRI brain image demonstrating volumetric mensuration of the fourth ventricle. 
since Tamhane test was used for this comparison. Nonparametric continuous variables were compared by the analysis of the medians using Kruskal-Wallis test, and later, the significant variables were submitted to Student-Newman-Keuls test. Pearson's correlation test between age and percentage of the total ventricular volume by intracranial volume was also performed in this study. The level of statistical significance for all tests was set at $5 \%(p<0.05)$.

\section{RESULTS}

Temporal horns of the lateral ventricles were observed in $3 / 12$ adult, 6/11 mature and 9/10 geriatric cats, resulting in significant difference between adult and mature animals in relation to geriatric animals $(\mathrm{P}=0.007)$.

No significant difference between groups $(\mathrm{P}=0.651)$ were found for the evidence of the olfactory bulb cavities, which were visualized in 4/12 adult, 2/11 mature and 2/10 geriatric cats. In the adult group, right olfactory bulb cavity was evidenced in $2 / 4$ animals (50\%) and, in the other $2 / 4$ animals (50\%), both cavities were visualized. In the mature group, only the left cavity was identified in $2 / 2$ cats $(100 \%)$. In the geriatric group, the left olfactory bulb cavity was observed in $1 / 2$ cat $(50 \%)$ and bilateral cavities were seen in $1 / 2$ animal (50\%). Percentages of the volume of the ipsilateral lateral ventricle by intracranial volume determined in these cats were higher than the average value found for adults in $3 / 4$ adult $(75 \%)$, $1 / 2$ mature $(50 \%)$ and $2 / 2$ geriatric $(100 \%)$ cats. Furthermore, volumes of the ipsilateral lateral ventricles were considered the greatest ones of each group in $3 / 4$ adult (75\%), $1 / 2$ mature $(50 \%)$ and $1 / 2$ geriatric (50\%) animals.

Geriatric cats showed significantly higher values in comparison to the adults for the percentages of the right lateral and third ventricles volumes in relation to intracranial volume, as well as for the percentage related to the total ventricular volume (Table 1-4).

Table 1. Mean, standard deviation, minimum and maximum values, and p-values of the comparison of the parametric continuous variables between adult, mature and geriatric cats

\begin{tabular}{|c|c|c|c|c|c|c|c|}
\hline Parameters & Groups & $\mathrm{N}$ & Mean & SD & Minimum & Maximum & P value \\
\hline \multirow{3}{*}{$\begin{array}{l}\text { Mesencephalic aqueduct } \\
\text { volume x100/intracranial } \\
\text { volume (\%) }\end{array}$} & A & 12 & 0.02 & 0,00 & 0.01 & 0.02 & \multirow[t]{3}{*}{0.121} \\
\hline & B & 11 & 0.02 & 0.01 & 0.01 & 0.05 & \\
\hline & $\mathrm{C}$ & 10 & 0.02 & 0.01 & 0.01 & 0.04 & \\
\hline $\mathrm{x} 100 /$ intracranial volume & B & 11 & 0.03 & 0.01 & 0.01 & 0.05 & \multirow{2}{*}{0.078} \\
\hline & $\mathrm{C}$ & 10 & 0.04 & 0.01 & 0.02 & 0.06 & \\
\hline $\begin{array}{l}\text { x100/intracranial volume } \\
(\%)\end{array}$ & $\mathrm{C}$ & 10 & 0.47 & 0.21 & 0.27 & 0.92 & \\
\hline
\end{tabular}

$\mathrm{A}=$ Adult cats, $\mathrm{B}=$ mature cats, $\mathrm{C}=$ geriatric cats, $\mathrm{SD}=$ standard deviation; ${ }^{*}$ Statistically significant difference between groups $(\mathrm{P}<0.05)$.

Table 2. Standard error and p-value obtained in the multiple comparison test of the parametric continuous variable with significant p-value between adult, mature and geriatric cats

\begin{tabular}{lccc}
\hline \multicolumn{1}{c}{ Parameter } & Groups & Standard error & Pvalue \\
\hline Total ventricular volume $x$ 100/ & A x B & 0.07 & 0.155 \\
intracranial volume (\%) & A x C & 0.07 & $0.002^{*}$ \\
& B x C & 0.09 & 0.257
\end{tabular}

$\overline{\mathrm{A}=\text { Adult cats, } \mathrm{B}}=$ mature cats, $\mathrm{C}=$ geriatric cats; $*$ Statistically significant difference between groups $(\mathrm{P}<0.05)$.

Table 3. Median, minimum and maximum values, and p-value of the comparison of the non-parametric continuous variables between adult, mature and geriatric cats

\begin{tabular}{|c|c|c|c|c|c|c|}
\hline Parameters & Groups & $\mathrm{N}$ & Median & Minimum & Maximum & $P$ value \\
\hline \multirow{3}{*}{$\begin{array}{l}\text { Right lateral ventricle } \\
\text { volume x } 100 / \text { intracranial } \\
\text { volume }(\%)\end{array}$} & A & 9 & 0.03 & 0.01 & 0.11 & \multirow[t]{3}{*}{$0.010^{*}$} \\
\hline & B & 8 & 0.09 & 0.01 & 0.24 & \\
\hline & $\mathrm{C}$ & 10 & 0.17 & 0.04 & 0.26 & \\
\hline \multirow{3}{*}{$\begin{array}{l}\text { Left lateral ventricle } \\
\text { volume x } 100 / \text { intracranial } \\
\text { volume }(\%)\end{array}$} & A & 8 & 0.05 & 0.01 & 0.11 & \multirow[t]{3}{*}{0.077} \\
\hline & B & 9 & 0.08 & 0.01 & 0.41 & \\
\hline & $\mathrm{C}$ & 10 & 0.11 & 0.03 & 0.48 & \\
\hline \multirow{3}{*}{$\begin{array}{l}\text { Third ventricle volume } \\
\text { x100/intracranial volume } \\
(\%)\end{array}$} & A & 12 & 0.05 & 0.02 & 0.11 & \multirow[t]{3}{*}{$0.047^{*}$} \\
\hline & B & 11 & 0.07 & 0.04 & 0.05 & \\
\hline & $\mathrm{C}$ & 10 & 0.09 & 0.01 & 0.24 & \\
\hline
\end{tabular}

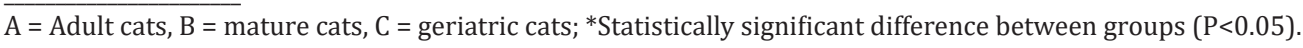


Considering the average percentages of the ventricular volumes in relation to intracranial volume, there was an increase in the values related to the right lateral ventricle of $0.078 \%$ between adult and mature cats and $0.038 \%$ between mature and geriatric cats. Assuming the percentage determined for the adults as basis, it was observed ventricular increase of $210.81 \%$ between adult and mature cats and $102.70 \%$ between mature and geriatric cats.

Percentage of the third ventricle volume in relation to intracranial volume increased $0.019 \%$ between adult and mature animals and $0.027 \%$ between mature and geriatric cats. Considering the percentage calculated for the adults as basis, there was an increase in the third ventricle volume of $37.26 \%$ between adult and mature cats and $52.94 \%$ between mature and geriatric cats.

Estimated annual increase rates of the percentage of the ventricular volume in relation to intracranial volume, using the difference between the mean age of the groups, were $32.23 \%$ for the right lateral ventricle and $5.70 \%$ for the third ventricle in the early phase (between adult and mature groups) and $18.81 \%$ for the right lateral ventricle and $9.70 \%$ for the third ventricle in the late phase (between mature and geriatric groups).

Figure 6 illustrates the significant increase in the size of the right lateral ventricle (including temporal horns) and third ventricle as advancing age.

Mean value related to the percentage of the total ventricular volume in relation to intracranial volume increased about $0.18 \%$ between adult and mature cats and $0.11 \%$ between mature and geriatric animals. Assuming the percentage found for adults as basis, there was ventricular enlargement of $100 \%$ between adult and mature cats and $61.11 \%$ between mature and geriatric cats.

Annual increase rates of the total ventricular volume corrected for the intracranial volume estimated in this study, based on the difference between the mean ages of the groups, were $15.29 \%$ in the early phase and $11.19 \%$ in the late phase.

Pearson's correlation test showed strong positive correlation between age and percentage of the total ventricular volume by intracranial volume.

Volume of the olfactory bulb cavitites (Table 5) could not be statistically compared in this study since the sample size was considered insufficient.

Table 4. P-values obtained in the multiple comparison tests of non-parametric continuous variables with significant p-values between adult, mature and geriatric cats

\begin{tabular}{|c|c|c|c|}
\hline Comparisons & $\mathrm{A} \times \mathrm{B}$ & $\mathrm{A} \times \mathrm{C}$ & $\mathrm{B} \times \mathrm{C}$ \\
\hline $\begin{array}{l}\text { Right lateral ventricle volume x100/ } \\
\text { intracranial volume (\%) }\end{array}$ & 0.105 & $0.002^{*}$ & 0.204 \\
\hline Third ventricle volume x100/ & 0.086 & $0.018^{*}$ & 0.490 \\
\hline
\end{tabular}

intracranial volume $(\%)$

$\overline{\mathrm{A}=\text { Adult cats, } \mathrm{B}}=$ mature cats, $\mathrm{C}=$ geriatric cats; *Statistically significant difference between groups $(\mathrm{P}<0.05)$.

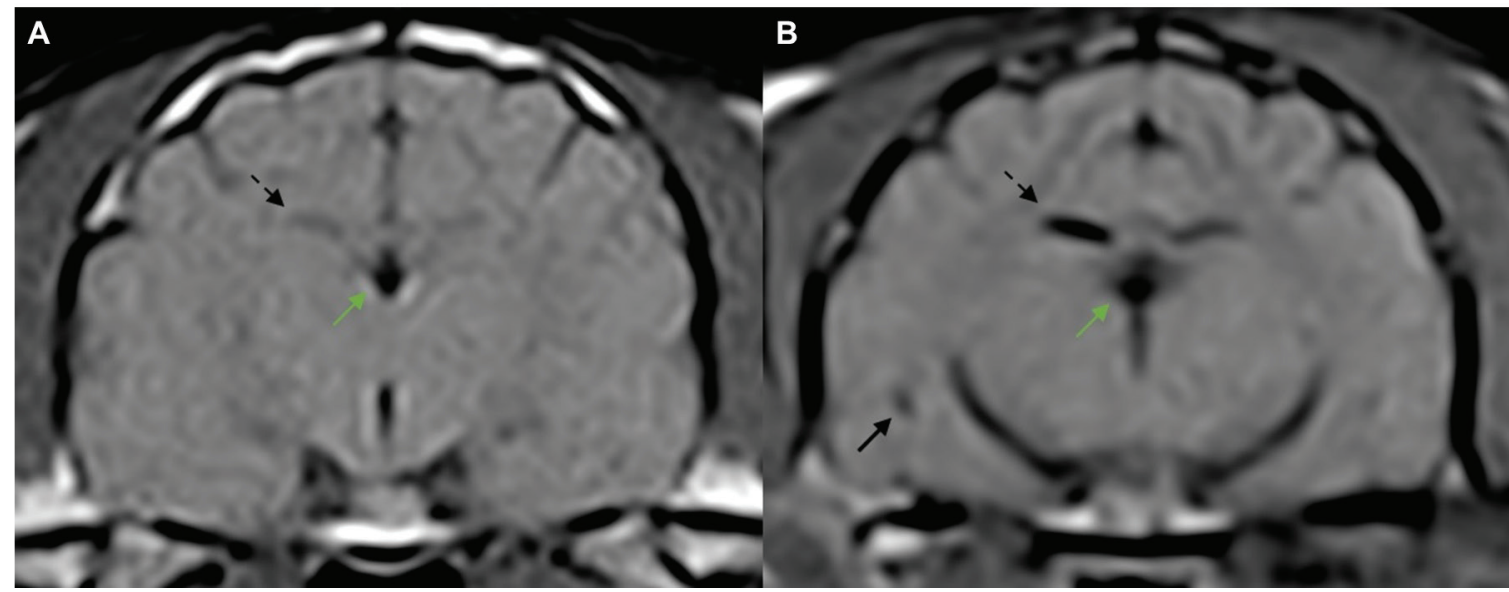

Fig.6. MRI brain images of (A) 2-year-old female adult cat and (B) 12-year-old geriatric cat, illustrating tendency of expansion of the right

lateral ventricle (dashed arrow), including the temporal horns (arrow), and third ventricle (green arrow) as advancing age.

Table 5. Mean, standard deviation, and minimum and maximum values of the volume of the olfactory bulb cavities of adult, mature and geriatric cats

\begin{tabular}{|c|c|c|c|c|c|c|}
\hline Parameters & Groups & $\mathrm{N}$ & Mean & SD & Minimum & Maximum \\
\hline \multirow{3}{*}{$\begin{array}{l}\text { Right olfactory bulb } \\
\text { cavity volume }\left(\mathrm{mm}^{3}\right)\end{array}$} & $A$ & 4 & 5.21 & 1.39 & 3.36 & 6.46 \\
\hline & B & 0 & - & - & - & - \\
\hline & $\mathrm{C}$ & 1 & 5.20 & - & 5.20 & 5.20 \\
\hline \multirow{3}{*}{$\begin{array}{l}\text { Left olfactory bulb cavity } \\
\text { volume }\left(\mathrm{mm}^{3}\right)\end{array}$} & A & 2 & 4.75 & 1.09 & 3.97 & 5.52 \\
\hline & B & 2 & 8.18 & 2.32 & 6.54 & 9.82 \\
\hline & $\mathrm{C}$ & 2 & 4.05 & 0.56 & 3.65 & 4.45 \\
\hline
\end{tabular}

$\overline{\mathrm{A}=\text { Adult cats, } \mathrm{B}}=$ mature cats, $\mathrm{C}=$ geriatric cats, $\mathrm{SD}=$ standard deviation. 


\section{DISCUSSION}

The significant increase of the corrected volumes of the right lateral and third ventricles in geriatric cats compared to the adults suggests that ventricular dilation tends to occur in cats as advancing age, as identified in humans (Coffey et al. 1992, Resnick et al. 2000, Beason-Held \& Horwitz 2002, Sullivan et al. 2002, Walhovd et al. 2005), rodents (Chen et al. 2011) and dogs (Gonzalez-Soriano et al. 2001, Su et al. 2005). In a longitudinal study, it was found that 26 of 47 (55.3\%) dogs showed increase in volume of the lateral ventricles comparing the images of the second year in relation to the first one, and 35 of 41 (85.37\%) dogs showed higher values in the third year of the study in comparison to the second one (Su et al. 2005). In another research, a high frequency of mild to moderate ventricular dilation was detected in older dogs $(60 \%)$, constantly verified in animals older than 14 years of age (Borràs et al. 1999).

Exclusive expansion of the right lateral ventricle in the cats of this study may be justified by the occurrence of asymmetric brain atrophy, as had been found in humans, which showed pronounced volumetric reduction of the left temporal lobe compared to the right (Resnick et al. 2003).

The tendency to third ventricular dilation in cats corroborates with the findings reported in humans (Coffey et al. 1992, Walhovd et al. 2005) and rodents (Chen et al. 2011). However, it is not consistent with the results from a previous study in dogs, since no significant differences were found for the third ventricular dimensions between adult and geriatric German Shepherd dogs (Gonzalez-Soriano et al. 2001).

The comparison of the corrected ventricular volumes between groups suggests a tendency to acceleration in the expansion rate of the right lateral ventricle in the early phase and third ventricle in the late phase, as reported in rodents (Chen et al. 2011).

Analyzing the percentage of the total ventricular volume by intracranial volume, it was detected that the total ventricular dilation rate was higher between adults and mature cats. This finding differs from the results reported in a human study in which a greater increase in the total volume of the intracranial cerebrospinal fluid was identified between mature and geriatric individuals (Matsumae et al. 1996); and the findings of another research, since it was observed acceleration in ventricular expansion in advanced age in humans (Walhovd et al. 2005). However, the data found for cats are consistent with the findings reported in rodents, which demonstrates the occurrence of a greater ventricular dilation in the early phase (Chen et al. 2011).

Strong positive correlation was found between age and percentage of the total ventricular volume by intracranial volume ( $r=0.631)$, which, although consistent with the expected results, differs from that reported in humans, who showed weak positive association between age and cerebrospinal fluid volume (Jancke et al. 2015).

The significant increase of the evidence of the temporal horns in geriatric cats in relation to the adult and mature cats suggests the expansion of this ventricular structure according to the progression of age. This finding corroborates that reported in dogs, in which the enlargement of the temporal ventricular horn is considered an early marker related to senility (Pugliese et al. 2010). As the expansion of this ventricular structure is correlated with hippocampal atrophy in dogs (Pugliese et al. 2010), the significant increase in the evidence of the temporal ventricular horns in cats suggests the occurrence of hippocampal volumetric reduction with age in these animals.

In humans, it has been found that the olfactory bulb cavities are identified more frequently in the group of the younger individuals (age $<45$ years: $67 \%$, age $>45$ years: $48 \%$ ) (Smitka et al. 2009), as observed in the cats of this study. According to some authors, the reduction of the lateral ventricular dimensions as the progression of age in the early stage of life in humans is accompanied by a concomitant decrease of the evidence of the olfactory bulb cavities (Yousem et al. 1998, Buschhüter et al. 2008).

The results of this study suggest a correlation between dilation of the lateral ventricles and olfactory bulb cavities, as reported in dogs (Kim et al. 2009). However, unlike cats, dogs showed neurological signs (Kim et al. 2009), since the expansion of the olfactory bulb cavities in these animals is associated with increased intracranial pressure at later stages (Platt \& Garosi 2012, Laubner et al. 2015). Intracranial pressure was not measured in this research; however, imaging findings related to increased intracranial pressure, such as periventricular edema and thinning of the grooves and/or subarachnoid space were not observed (Laubner et al. 2015).

\section{CONCLUSIONS}

This study tends to confirm the hypothesis that domestic cats suffer expansion of the cerebral ventricular system with the progression of age, as well as increase in frequency of the temporal ventricular horns identification.

Some limitations occurred in this study such as the use of low-field MRI equipment and reduced number of cats. Thus, further researches investigating a larger amount of cats, healthy and with cognitive dysfunction syndrome, using a high-field MRI system is required in order to determine additional age-related changes of the cerebral ventricles.

Acknowledgements.- This study was supported by the Fundação de Amparo à Pesquisa do Estado de São Paulo (2013/06148-0 and 2012/18750-3).

\section{REFERENCES}

Bagley R.S. 2005. Fundamentals of Veterinary Clinical Neurology. Blackwell Publishing, Iowa. 570p.

Beason-Held L.L. \& Horwitz B. 2002. Aging brain, p.43-57. In: Ramachandran V.S. (Ed), Encyclopedia of the Human Brain. Academic Press, New York. <http://dx.doi.org/10.1016/B0-12-227210-2/00009-1>.

Borràs D., Ferrer I. \& Pumarola M. 1999. Age-related changes in the brain of the dog. Vet.Pathol. 36(3):202-211. <http://dx.doi.org/10.1354/vp.36-3202> <PMid:10332828>

Buschhüter D., Smitka M., Puschmann S., Gerber J.C., Witt M., Abolmaali N.D. \& Hummel T. 2008. Correlation between olfactory bulb volume and olfactory function. Neuroimage 42(2):498-502. <http://dx.doi.org/10.1016/j. neuroimage.2008.05.004> <PMid:18555701>

Chen C.C., Tung Y.Y. \& Chang C. 2011. A lifespan MRI evaluation of ventricular enlargement in normal aging mice. Neurobiol. Aging 32(12):2299-2307. <http://dx.doi.org/10.1016/j.neurobiolaging.2010.01.013><PMid:20137831>

Coffey C.E., Wilkinson W.E., Parashos L.A., Soady S.A., Sullivan R.J., Patterson L.J., Figiel G.S., Webb M.C., Spritzer C.E. \& Djang W.T. 1992. Quantitative cerebral anatomy of the aging human brain: a cross-sectional study using 
magnetic resonance imaging. Neurology 42 (3 Pt 1):527-536. <http:// dx.doi.org/10.1212/WNL.42.3.527><PMid:1549213>

Eisenberg R.L. 2010. Clinical Imaging: an Atlas of Differential Diagnosis. 5th ed. Wolters Kluwer Health/Lippincott Williams and Wilkins, Philadelphia. 1442p.

Evans H.E. 1993. Miller's Anatomy of the Dog. 3rd ed. W.B. Saunders, Philadelphia. 1113p.

Evans H.E. \& DeLahunta A. 2001. Guia para a Dissecção do Cão. 5ํㅗ ed. Guanabara Koogan, Rio de Janeiro. 250p.

Fortney W.D. 2012. Implementing a successful senior/geriatric health care program for veterinarians, veterinary technicians, and office managers. Vet. Clin. N. Am., Small Anim. Pract. 42(4):823-834, viii. <http://dx.doi. org/10.1016/j.cvsm.2012.04.011><PMid:22720816>

González-Soriano J., Marín García P., Contreras-Rodríguez J., Martínez-Sainz P. \& Rodríguez-Veiga E. 2001. Age-related changes in the ventricular system of the dog brain. Ann. Anat. 183(3):283-291. <http://dx.doi.org/10.1016/ S0940-9602(01)80236-3><PMid:11396800>

Jäncke L., Mérillat S., Liem F. \& Hänggi J. 2015. Brain size, sex, and the aging brain. Hum. Brain Mapp. 36(1):150-169. <http://dx.doi.org/10.1002/ hbm.22619><PMid:25161056>

Kim J.H., Jeon H.W., Woo E.J. \& Park H.M. 2009. Dilation of the olfactory bulb cavity concurrent with hydrocephalus in four small breed dogs. J. Vet. Sci. 10(2):173-175. <http://dx.doi.org/10.4142/jvs.2009.10.2.173> <PMid:19461216>

Laflamme D. \& Gunn-Moore D. 2014. Nutrition of aging cats. Vet. Clin. N. Am., Small Anim. Pract. 44(4):761-774, vi. <http://dx.doi.org/10.1016/j. cvsm.2014.03.001><PMid:24951345>

Laubner S., Ondreka N., Failing K., Kramer M. \& Schmidt M.J. 2015. Magnetic resonance imaging signs of high intraventricular pressure - comparison of findings in dogs with clinically relevant internal hydrocephalus and asymptomatic dogs with ventriculomegaly. BMC Vet. Res. 11(1):181. <http://dx.doi.org/10.1186/s12917-015-0479-5> <PMid:26231840>

Lund E.M., Armstrong P.J., Kirk C.A., Kolar L.M. \& Klausner J.S. 1999. Health status and population characteristics of dogs and cats examined at private veterinary practices in the United States. J. Am. Vet. Med. Assoc. 214(9):1336-1341. <PMid:10319174>

Matsumae M., Kikinis R., Mórocz I.A., Lorenzo A.V., Sándor T., Albert M.S., Black P.M. \& Jolesz F.A. 1996. Age-related changes in intracranial compartment volumes in normal adults assessed by magnetic resonance imaging. J. Neurosurg. 84(6):982-991. <http://dx.doi.org/10.3171/jns.1996.84.6.0982> $<$ PMid:8847593>

Platt S. \& Garosi L. 2012. Hydrocephalus, p.116-117. In: Platt S. \& Garosi L. (Eds), Small Animal Neurological Emergencies. Manson Publishing Ltd/ The Veterinary Press, London. <http://dx.doi.org/10.1201/b15214>.
Pugliese M., Carrasco J.P., Gomez-Anson B., Andrade C., Zamora A., Rodríguez M.J., Mascort J. \& Mahy N. 2010. Magnetic resonance imaging of cerebral involutional changes in dogs as markers of aging: an innovative tool adapted from a human visual rating scale. Vet. J. 186(2):166-171. <http://dx.doi. org/10.1016/j.tvjl.2009.08.009><PMid:19748805>

Resnick S.M., Pham D.L., Kraut M.A., Zonderman A.B. \& Davatzikos C. 2003. Longitudinal magnetic resonance imaging studies of older adults: a shrinking brain. J. Neurosci. 23(8):3295-3301.<http://dx.doi.org/10.1523/ JNEUROSCI.23-08-03295.2003><PMid:12716936>

Resnick S.M., Goldszal A.F., Davatzikos C., Golski S., Kraut M.A., Metter E.J., Bryan R.N. \& Zonderman A.B. 2000. One-year age changes in MRI brain volumes in older adults. Cereb. Cortex 10(5):464-472. <http://dx.doi. org/10.1093/cercor/10.5.464><PMid:10847596>

Scahill R.I., Frost C., Jenkins R., Whitwell J.L., Rossor M.N. \& Fox N.C. 2003. A longitudinal study of brain volume changes in normal aging using serial registered magnetic resonance imaging. Arch. Neurol. 60(7):989-994. <http://dx.doi.org/10.1001/archneur.60.7.989><PMid:12873856>

Smitka M., Abolmaali N., Witt M., Gerber J.C., Neuhuber W., Buschhueter D., Puschmann S. \& Hummel T. 2009. Olfactory bulb ventricles as a frequent finding in magnetic resonance imaging studies of the olfactory system. Neuroscience 162(2):482-485. <http://dx.doi.org/10.1016/j. neuroscience.2009.04.058><PMid:19401222>

Su M.-Y., Tapp P.D., Vu L., Chen Y.F., Chu Y., Muggenburg B., Chiou J.Y., Chen C., Wang J., Bracco C. \& Head E. 2005. A longitudinal study of brain morphometricsusing serial magnetic resonance imaging analysis in a canine model of aging. Prog.Neuropsychopharmacol. Biol. Psychiatry 29(3):389397. <http://dx.doi.org/10.1016/j.pnpbp.2004.12.005><PMid:15795047>

Sullivan E.V., Pfefferbaum A., Adalsteinsson E., Swan G.E. \& Carmelli D. 2002. Differential rates of regional brain change in callosal and ventricular size: a 4-year longitudinal MRI study of elderly men. Cereb. Cortex 12(4):438445. <http://dx.doi.org/10.1093/cercor/12.4.438> <PMid:11884358>

Thomas W.B. 2010. Hydrocephalus in dogs and cats. Vet. Clin. N. Am., Small Anim. Pract. 40(1):143-159. <http://dx.doi.org/10.1016/j.cvsm.2009.09.008> <PMid:19942061>

Walhovd K.B., Fjell A.M., Reinvang I., Lundervold A., Dale A.M., Eilertsen D.E., Quinn B.T., Salat D., Makris N. \& Fischl B. 2005. Effects of age on volumes of cortex, white matter and subcortical structures. Neurobiol. Aging 26(9):1261-1270.<http://dx.doi.org/10.1016/j.neurobiolaging.2005.05.020> $<$ PMid:16005549>

Yousem D.M., Geckle R.J., Bilker W.B. \& Doty R.L. 1998. Olfactory bulb and tract and temporal lobe volumes. Normative data across decades. Ann. N.Y. Acad. Sci. 855(1):546-555.<http://dx.doi.org/10.1111/j.1749-6632.1998. tb10624.x><PMid:9929650> 